Portland State University

PDXScholar

$5-25-2017$

\title{
Contemporary Attitudes Towards the Senpai-Kōhai Relationship
}

Michiko Yoshinaga

Portland State University

Follow this and additional works at: https://pdxscholar.library.pdx.edu/honorstheses Let us know how access to this document benefits you.

\section{Recommended Citation}

Yoshinaga, Michiko, "Contemporary Attitudes Towards the Senpai-Kōhai Relationship" (2017). University Honors Theses. Paper 376.

https://doi.org/10.15760/honors.375

This Thesis is brought to you for free and open access. It has been accepted for inclusion in University Honors Theses by an authorized administrator of PDXScholar. Please contact us if we can make this document more accessible: pdxscholar@pdx.edu. 
Contemporary Attitudes Towards the Senpai-Kōhai Relationship Michiko Yoshinaga 1

\author{
PORTLAND STATE UNIVERSITY
}

HONORS COLLEGE

CONTEMPORARY JAPANESE ATTITUDES TOWARDS THE SENPAI-KŌHAI RELATIONSHIP

AN UNDERGRADUATE HONORS THESIS SUBMITTED TO THE HONORS COLLEGE

in partial fulfillment of the requirements for the

Degree of

BACHELOR OF ARTS

JAPANESE

By

MICHIKO YOSHINAGA

Thesis Advisor

DR. PATRICIA J. WETZEL

Portland State University 
Contemporary Attitudes Towards the Senpai-Kōhai Relationship Michiko Yoshinaga 2

Dedicated to Irina Gabashvili

The best mother I could ask for 
Contemporary Attitudes Towards the Senpai-Kōhai Relationship Michiko Yoshinaga 3

\section{ACKNOWLEDGEMENTS}

I would first like to thank my thesis advisor Dr. Patricia J. Wetzel. I am deeply grateful for her support and guidance in the writing of this thesis. I am honored to have had the ability to work with her over the last nine months. This thesis would not have been possible without her, and I am eternally grateful for her time and effort. I have learned so much from her, and words cannot express how grateful I am for her support over the last four years. Wetzel-sensei, thank you so much for everything!

I would also like to thank my family for supporting me and encouraging me to keep fighting and keep trying. Your love and support has kept me going.

And to my friends and colleagues both in America and Japan, thank you for continuing to support me all these years. I am grateful for all the great people I have in my life. 


\begin{abstract}
The importance of the senpai-kōhai 'senior-junior' relationship is of utmost importance to the working of Japanese society starting from a young age. Children become conscious of the relationship most earnestly in junior high school and quickly become socialized to adhere to rules regarding appropriate behavior and language use and duties. My research attempts to shed light on contemporary attitudes towards the senpai-kōhai relationship by addressing the overarching question "what are contemporary attitudes toward the senpai-kôhai relationship?" I also address the subtopics of importance of the relationship, evidence of ambivalence, consciousness, and how the relationship is perceived to be recognized linguistically.
\end{abstract}

Key words: Attitudes, Japanese Sociolinguistics, Senpai-Kōhai Relationship, Jōge-Kankei

\title{
$\underline{\text { Introduction }}$
}

The senpai-kōhai 'senior-junior' relationship in Japan is conventionally governed by expectations regarding language use. The kōhai speaks to their senpai in keigo, or honorific language, and the senpai returns the kōhai's respect by, among other things, taking care of their subordinate. It is a vertical relationship that reflects a fundamental difference in status. The senpai is older than the kōhai (changes in modern society notwithstanding), and almost always entered the school or company in question before the kōhai (Sano 2014). In practice, this gives the senpai more knowledge and experience than the kōhai, granting them the position of leadership. Due to the higher status of senpai, kōhai are expected to use honorific language when talking to senpai. Other concomitant expectations include not disrupting interpersonal harmony by outwardly stating their opinions (especially if there is a chance that it could contradict the senpai) or otherwise embarrassing their senpai (Reizei 2012). While there are rigid expectations for kōhai to abide by these cultural norms, they also benefit by 
Contemporary Attitudes Towards the Senpai-Kōhai Relationship Michiko Yoshinaga 5

being recipients of amae, or dependence, from senpai. Senpai are expected to look after their kōhai and act as role models (Takeishi 2010).

\section{Literature Review}

It is often said that Japan is a collectivistic culture, and that people tend to prefer working in groups and blending in, not wanting to be the odd one out (Lebra 1976). In fact there is a saying that the nail that sticks out gets hammered down (Deru kugi wa utareru). Concepts such as wa (harmony), amae (dependence), enryo (restraint), and kaizen (selfimprovement) all play roles in maintaining a productive and peaceful society. The senpaikōhai relationship embodies aspects of all these concepts in a web where one concept cannot exist without another. For example, amae as a cultural construct of relying on another for their superior wisdom and experience relies on a fundamental difference in status between two parties. Similarly, the senpai-kōhai relationship underlies wa.

Creighton (1998) and Sano (2014) agree that the senpai-kōhai relationship is important as it allows kōhai to depend on their senpai to take care of them, which plays a crucial role in maintaining group harmony (another highly valued attribute of groups in Japan). Since the senpai typically have more knowledge and experience regarding the functioning of the organization in question, they have the upper hand when it comes to leadership and decision making. As kōhai are subordinates, they can have a sense of guiltless 
Contemporary Attitudes Towards the Senpai-Kōhai Relationship Michiko Yoshinaga 6

reliance on the senpai and learn by watching how their seniors approach a given chore. This dependence, or amae, on the senpai, as well as the kōhai's usage of honorific language (keigo) to the senpai maintain a sense of interpersonal harmony ( $w a)$, aiding both a sense of connectivity as well as efficiency. Amae is seen by many scholars including Heine et al (2000), Reizei (2012), and Takeishi (2010) as an important factor in maintaining harmony on many fronts in Japan, most especially that between senpai and kōhai. If senpai do their duty of taking care of the kōhai by helping them with a wide range of tasks, the kōhai are expected to return the favor with loyalty and respect (which are reflected in how the kōhai speak and interact with the senpai).

Furthermore, senpai are expected to take leadership roles in organizing events, meetings, etc. (Creighton 1998; Miller 2013; Takeishi 2010), especially when it comes to club activities in schools. It should be noted that this senpai-kōhai socialization begins in earnest in junior high school (as my data sample also reflects). Takeishi further emphasizes that activities are led by senpai with "little input" from kōhai. Miller stresses the importance of the senpai-kōhai relationship in not only club activities (junior high school through college), but the work world as well. Creating what anthropologists call "fictional" familytype bonds and promoting harmony and inner-group respect are important cultural values in Japanese society (Miller 2013). These bonds are part of the concept $u c h i$, or in-group, where members of the same group or cause work together. In turn, adherence to the senpai-kohai 
Contemporary Attitudes Towards the Senpai-Kōhai Relationship Michiko Yoshinaga 7

relationship can enhance this sense of harmony and respect (Sano 2014).

Tying in with the importance of $w a$, Heine et. al. (2000) suggest that although many

Westerners believe that there is a universal necessity of positive self-regard in terms of boosting one's efficiency, the Japanese seem to require a positive view from others rather than from oneself. This manifests itself when Japanese aim for approval through selfimprovement as opposed to self-enhancement. Within Japanese society outward promotion of self is frowned upon as it interferes with group harmony. In fact, self-criticism is often seen as beneficial as it requires self-reflection and evaluation, showing not only one's humility but also the willingness to show one's imperfections. So rather than showing confidence in one's abilities to do things individually, Japanese tend to work in groups, learning from others' experiences and wisdom. Rohlen (1979) describes $w a$ as a crucial connector that helps show the group/organization's strengths. Working harmoniously in a group while discreetly working to improve oneself through the process of improving one's own abilities and skills (改善 kaizen), Rohlen and Heine et. al. argue, the organization is made stronger as a direct result of group effort and teamwork.

When both senpai and kōhai work together toward a common goal, although their jobs and responsibilities may differ, they both have an obligation to each other, and when both respond to each other appropriately, group harmony is maintained, mutual respect is attained, and the group can continue to grow. Thus the importance of this relationship cannot 
Contemporary Attitudes Towards the Senpai-Kōhai Relationship Michiko Yoshinaga 8

be overstated.

\section{$\underline{\text { Research Questions }}$}

The importance of the senpai-kôhai relationship in Japanese society motivated me to study contemporary attitudes towards the senpai-kōhai relationship and its relevance to Japanese people. I seek to answer the overarching question, "What are contemporary Japanese attitudes towards the senpai-kōhai relationship?" In answering this question, I will address the sub-topics: 1. Do Japanese people think the senpai-kōhai relationship is important? 2. Is there evidence of ambivalence? 3. When does consciousness of the senpaikōhai relationship begin? 4. How do people perceive the senpai-kōhai relationship to be recognized linguistically?

\section{Research Instrument Description}

From summer 2015 to spring 2016 I conducted an informal survey (Appendix A) of people's attitudes toward the senpai-kōhai relationship. My informal survey was intended to answer some quantitative and qualitative questions about the relationship. This survey was created and distributed in July 2015 (although I also received responses as late as February and March of the next year) to friends and acquaintances who I thought would have interesting opinions about the senpai-kōhai relationship. At the time I had not finalized my research question or thesis, so some of the questions I asked have little to no relevance to the 
current thesis. Due to the informal nature of the survey, there are weaknesses in using it as a data sample. One of the biggest weaknesses in the survey is the flawed nature of some of the questions. For example, one of the questions is, "In terms of Japan, do you think the senpaikōhai relationship is necessary?" The issue with this question is that no social convention is "necessary"; in terms of Japan, the senpai-kōhai relationship is important, but I ascribe too much importance to it if I ask about its "necessity." Another weakness is in regards to the fact that my data sample includes primarily people I know on a personal level - I chose both people who lived/studied abroad as well as people who spent most of their lives in Japan (having only been outside to travel). There are some exceptions but at the time I was actively getting informants, I was researching a different topic that prompted me to pursue the survey less objectively. Thus the sample cannot be said to be representative or randomly selected in terms of any demographic factors (such as age, gender, dialect, social class, etc.). It nonetheless generated responses that can be analyzed qualitatively and perhaps lay the foundation for more systematic controlled research to follow. 


\section{$\underline{\text { Results }}$}

\section{Analyzing the Data}

The data, which can be found in Appendix A, are formatted according to Questions numbered 1-10, with Responses from each respondent numbered 1-33 following each question. The raw data are untranslated and identifying information of the individual has been removed.

Data used in this thesis to answer the research questions were pulled by the author from the sample because of their relevance to the topic and sub-topics. At the time the questionnaire was distributed, since the topic of study was not finalized, some questions were rendered irrelevant to the current area of study. The full questionnaire is in Appendix B following the raw data. I used Google Docs for distribution of the questionnaire and collection of responses. I transcribed the raw data (Appendix A) into Google Docs.

While the raw data seen in Appendix A are untranslated, data used in the results section were translated by the author. This is because I deemed certain responses to be reflective of the topics I was discussing. My methodology for translating responses is to convey as much information as possible without being untrue to the respondent's original intents. It should be noted, however, that the word 上下関係（jōge kankei） which is often defined as a "hierarchical relationship," is transcribed as "vertical relationship" for the purposes of this thesis. This is in an effort to avoid the social connotations of "hierarchy" in 
English. I wish to reflect the fact that the senpai-kohai affiliation reflects a fundamental difference in status between people, as opposed to being a power-based relationship.

\section{What are Contemporary Attitudes Toward the Senpai-Kōhai Relationship?}

Data collected from my questionnaire show a wide range of opinions in regard to the senpai-kōhai relationship. When I asked the question 先輩後輩関係についてどう思いま すか？(Q1: What do you think of the senpai-kōhai relationship?) There were many interpretations of the question itself. Some people gave their personal opinions of the senpaikōhai relationship while others gave context as to why they think the relationship is important or valuable to Japanese society. Some discussed how they view the relationship individually while others discussed the philosophical importance of the relationship. There was both positive and negative evaluation of the term, and the responses also show evidence of ambivalence (as I will discuss later in this section).

Thirteen (13) informants (Question 1 Responses 4, 6, 8, 10, 13, 14, 20, 21, 23, 24, 28,29 , and 32) reported that they thought the senpai-kōhai relationship was either "important," "necessary," or "valuable." One response stood out to me as being particularly reflective of the senpai-kōhai relationship:

\footnotetext{
先輩や後輩を持つことで、自分が学べることが多いと思います。どのように接すれば 先輩や後輩から慕ってもらえるのか知っておくことは、年功序列が主な日本の社会で 生きていく上では特に必要なことだと思います。また、憧れや理想像として先輩がい るのは目標になって良いことだと思いますし、自分が何かを教えてあげられたり自分
} 
についてきてくれたりする後輩も、人間として自分を高める上で大切な存在だと思い ます。

I think there are a lot of things one can learn just by having the senpai-kōhai relationship. I think it's really necessary to know how to deal with one's senpai and kōhai since Japan is a seniority-based society. Also, I think it's a good thing that there are senpai that you admire or are the "ideal image" of a senpai and that they become a goal (for how you want to be as a senpai), and that there is something you can teach your kōhai so they look up to you. I think it's an important existence (position) as it allows you as a person to improve (Q1 R3).

This response reflects the importance of the relationship to Japanese society, and how the senpai-kōhai relationship has affected the respondent personally. It also reflects part of what Miller (2013) discusses about family-type bonds: the individual looks up to their ideal senpai (who in a way is like an older sibling) and wants to adopt aspects of that senpai's behavior when the individual becomes a senpai themself.

In terms of those who gave personal opinions regarding the relationship, there were clear distinctions between those who thought positively of the relationship, those who thought negatively, and those who were either indifferent or did not evaluate the relationship, rather staying with commentary on why they think the relationship is important to Japanese society. The following are responses from those who view the relationship positively:

Q1 R7: 楽しい。後輩というだけで可愛く感じるし、先輩というだけで頼もしく感じ る。[The senpai-kōhai relationship] is fun. Just because I'm kōhai I'm cute, and just because I'm senpai I'm dependable.

Q1 R9: たいていの場合もあってもよいと思います。I think in most cases it's a good relationship to have.

Q1 R12: 生きた年数で立場に上下関係が生まれるということは、人によっては理不尽 に思うかもしれないが、能力により全てが判断されるよりは、全ての人間に対してあ る意味平等な価值基準であるといえる Although some people may think it is unreasonable that one's position in a vertical seniority-based relationship is decided 
based on the number of years (one has lived), I think it's more fair than being based solely on one's experiences/skills.

Q1 R16: 上下の繋がりがあるのはいいと思う。社会人の上司部下の関係の練習にもな る。I think having the vertical relationship [senpai-kōhai relationship] is nice. [The senpai-kōhai relationship] also serves as practice for the boss-subordinate relationship of working adults.

Q1 R17: あってもいいと思う。I think it's good to have [the senpai-kōhai relationship.]

Q1 R19：積極的に仲良くなりたい。I want to grow close in a positive way [with senpai and kōhai.]

Q1 R23：良い文化だと思う。I think it’s a good aspect of Japanese culture.

Responses like these were also common when I had conversations with friends about the senpai-kōhai relationship. One thing I was told frequently after someone had taken my questionnaire was that my questions made them think about the senpai-kōhai relationship in a way they never had before; they had to actually think about a relationship that is considered so straightforward and natural that no one actually talks about it beyond middle school age.

However, despite the optimistic views of the relationship, there were also some less positive responses. The following are responses that reflect negative thoughts about the senpai-kōhai relationship:

Q1 R1：ちょっとかたくるしい、めんどくさい時もある。It [the senpai-kōhai relationship] is a little stiff, and there are annoying times as well.

Q1 R22: 礼儀ある上下関係は伝統のひとつでもあるけれど、あまり囚われすぎると非 常に面倒くさく息苦しいものだと思います。A vertical relationship involving etiquette is one of those traditions, but I think if someone is too restrained, it's really obnoxious and suffocating [on a person.]

Q1 R26: 先輩を尊敬するのはいいことだと思うが、日本の上下関係は厳しすぎると思 う。I think respecting your senpai is a good thing, but I also think Japan's vertical relationships are too strict.

Q1 R32：大切だとは思うが、厳しすぎる上下関係はよくないと思う。I think [ the senpai-kōhai relationship] is important but I don't think the vertical relationships are 
good because they're too strict.

Q1 R33：年齢や会社、学校に入った年が少し上だというだけで立場がかなり変わるの は少し理不尽な気がします。I think it's a little unreasonable that the distance between two people changes so significantly just because the age between two people in either a company or school is a little different.

In conversations, just as I heard positive comments, I also heard opinions from people who view the senpai-kōhai relationship more negatively. That is, both the data I collected through the questionnaire, as well as conversations I had with friends reflect that while a majority of people tend to view the senpai-kōhai relationship positively, about $40 \%$ have some negative thoughts about the relationship.

\section{Is the Senpai-Kōhai Relationship Important to Japanese Society?}

In my survey I asked the question 日本において、先輩後輩関係は必要だと思い ますか。また、それは何故ですか。(Q2: In terms of Japan, do you think the senpai-kōhai relationship is necessary? Why or why not?). An overwhelming majority (79\% $\rightarrow 26 / 33$ people) of respondents answered that they think the senpai-kōhai relationship is necessary to Japanese society. Additionally, 3 people (9\%) said it was not necessary, and the remaining 4 $(12 \%)$ said that they could neither say it was necessary nor unnecessary.

Of those who view the senpai-kōhai relationship as necessary, two frequent comments stand out: 1. the senpai-kōhai relationship is an important factor in harmonious relations with colleagues; and 2. it is a relationship that has played a major role in Japanese society for a long time. Respondents tend to associate the senpai-kōhai relationship with 
human relations (how people interact with each other) in the workplace or with the social circle running smoothly (an example of $w a$ ); that is, the workplace or circle runs smoothly because there are cultural guidelines for how people are supposed to act.

On the other hand, among those who think the senpai-kōhai relationship is not necessary, one person said, “Although I don't remember any merits of having the senpaikōhai relationship, there are a lot of demerits such as bullying and the fact that you really can't say your opinion, so I really can't say it [the senpai-kōhai relationship] is necessary," (Q2 R33). Another respondent said, “It's unnecessary because I think people become friends when people are treated equally regardless of age," (Q2 R26). The third person who thought the senpai-kōhai relationship is not necessary did not give a specific reason.

Finally, the four people who did not take a positive or negative stand had different reasons for their opinions. The following are their responses:

Q2 R3: はっきりと必要だと言うことはできませんが、その方が社会が整理される気が します。歳だけでランクやレベリングされる日本は個人的には好きではありませんが、 その方が組織などを管理しやすいのではないかと思います。Although I can’t distinctly say [the senpai-kōhai relationship] is necessary, I get the feeling society is better organized [because of the existence of the senpai-kōhai relationship]. Although I personally do not like the Japan where people are ranked and leveled just by their age, I think that by doing so managing the organization is easier as a result.

Q2 R7: 絶対に必要というわけではないが、あった方がいいと思う。部活などにおいて 後輩は先輩に教わったり世話をしてもらったりするから、尊敬の念が必要なため。 Although it's not absolutely necessary, I think it's better if we have it. In terms of club activities, senpai teach kōhai and take care of them, so I think respect is necessary. Q2 R25: 必要？かなー？わからない。笑でも、上下関係はっきりするしいいとは思う。 Necessary? Maybe? I don't know. (haha) but I think it's good that we clearly define vertical relationships. 
Contemporary Attitudes Towards the Senpai-Kōhai Relationship Michiko Yoshinaga 16

Q2 R27: 必ずしも必要ではないがいままであったのだから、なくすことはできないと 思う。目上の人への尊敬を重んじる日本にとって先輩後輩関係は欠かせないと思う。 Although it is not entirely necessary, we've had the relationship up until now so I don't think it will ever disappear. In Japan we respect people above us, so I think the senpaikōhai relationship is indispensable.

Of these four responses, two cite that society is better off as a whole with the inclusion of the senpai-kōhai relationship, and this ties in with the respondents who view the senpai-kōhai relationship as necessary: the senpai-kōhai relationship helps Japanese society run better.

\section{Is there Evidence of Ambivalence?}

Ambivalent attitudes were included at the beginning of the Contemporary Attitudes section, but I will give more detail in this section. For the purposes of this thesis, ambivalence is defined as an opinion where differing or contradictory evaluations, thoughts, or attitudes are reflected in the individual's responses.

Some responses to questions 1 (What do you think of the senpai-kōhai relationship?) and 2 (In terms of Japan, do you think the senpai-kōhai relationship is necessary? Why or why not?) show ambivalence due to the seemingly contradictory evaluations given by the respondents.

For example, in response to question 1, there are three (3) cases of ambivalence I want to discuss. R9 (たいていの場合あってもよいと思います ‘For the most part [the senpai-kōhai relationship] is a good thing to have') is a good example of ambivalent thinking because while the respondent says "most cases" there is an underlying implication that there 
are situations where the senpai-kōhai relationship might not be useful or productive to either the individual or society as a whole. Similarly, R17 (あってもいいと思う ‘I think it's okay to have [the senpai-kōhai relationship]') also demonstrates a sense of peculiar vagueness. I take this to indicate that the respondent might have some conflicting thoughts.

For the last example from question 1, one respondent showed their ambivalent thinking very clearly: 大切だとは思うが、厳しすぎる上下関係はよくないと思う‘I think [the senpai-kōhai relationship] is important but I don't think the vertical relationships are good because they're too strict,' (Q1 R32). This respondent demonstrates ambivalent thoughts, saying that they view the senpai-kōhai relationship itself as a good thing, but that vertical relationships (which include the senpai-kōhai relationship) can be too demanding at times.

Finally, question 2 responses also reflect ambivalence. For example, R3 writes: はっきりと必要だと言うことはできませんが、その方が社会が整理される気がします。 歳だけでランクやレベリングされる日本は個人的には好きではありませんが、その方が 組織などを管理しやすいのではないかと思います。Although I can’t distinctly say [the senpai-kōhai relationship] is necessary, I get the feeling society is better organized [because of the existence of the senpai-kōhai relationship]. Although I personally do not like the Japan where people are ranked and leveled just by their age, I think that by doing so managing the organization is easier as a result (Q2 R3)

I interpret their final comment (they do not like that people are ranked and leveled according to age, but doing so helps manage the organization) to mean that "while I do not always like or agree with the senpai-kōhai relationship I do acknowledge its ability to help organizations run smoothly." Additionally, one respondent mentioned that while they thought the senpai- 
kōhai relationship was necessary, they do not think it is necessary to restrain their true feelings (be overly reserved or cautious about how to address) toward a senpai who has no skills or abilities compared to the individual (Q2 R24). So while they view the senpai-kohai relationship itself as a necessity, they do not believe in going above and beyond the call of duty for everyone; there are exceptions.

\section{When does Consciousness Begin?}

In order to pinpoint an approximate starting point and determine whether my data support current research about when consciousness of the senpai-kōhai relationship begins, I asked the question 具体的にいつ頃先輩後輩関係を意識するようになりましたか。 About when did you become conscious of the senpai-kōhai relationship? (Q4) Although there are a small number of people who became aware of the senpai-kōhai relationship during either elementary school or senior high school, the majority of my respondents $(85 \% \rightarrow 28$ out of 33 people) say that they became aware of the senpai-kōhai relationship in junior high school (middle school). This supports Takeishi's (2010) contention that socialization regarding senpai and kōhai typically begins through club activities in middle school. One of my respondents explained the phenomenon:

中学校に入学して、部活に入って先輩ができてからです。小学校でも部活に入ってい ましたが、そのときは先輩後輩関係はあまり意識していませんでした。中学校の部活 では、先輩と会ったときは立ち止まってお辞儀をして挨拶をする、という決まりがあ ったので、そのような特別な行動をとるようになったことがきっかけで、意識するよ 
Contemporary Attitudes Towards the Senpai-Kōhai Relationship Michiko Yoshinaga 19

うになったのだと思います。

After entering junior high school, I started club activities and (all of the sudden) I had senpai. Even in elementary school I did club activities, but during that time I didn't really become aware of the senpai-kōhai relationship. In junior high school club activities, however, there was a rule that when we saw senpai we had to stop , bow, and greet them, and because of that kind of special behavior I became conscious of the senpai-kōhai relationship, (Q4 R4).

Once students become conscious of the senpai-kōhai relationship, it will be with them for the rest of their life. The behavior described above is not unusual and stays relatively the same (different schools and clubs have different rules about the specific behavior students should partake in) even through college and on into the working world.

It is interesting, however, that there are respondents who say that they became conscious of the senpai-kōhai relationship either before or after junior high school. Of the 5 respondents who did not become conscious of the relationship in junior high school, 2 (6\%) became aware of the senpai-kōhai relationship in elementary school, $2(6 \%)$ became aware of it in high school, and $1(3 \%)$ lived abroad until college so did not experience the senpai-kōhai relationship until college.

One student pointed out that s/he became conscious of showing manners to people older than oneself (did not then know the terms senpai and kōhai but was actively taught to treat upperclassman differently than children of the same age) in elementary school. She wrote, "Although it's usual that from the time of junior high school on to use the terms "senpai" and "kōhai," I was careful to show proper etiquette and watch the way I talk around older students from the time I was in elementary school," (Q4 R12). 


\section{How do People Perceive the Senpai-Kōhai Relationship to be Recognized}

\section{Linguistically?}

The first and arguably most obvious sign of people perceiving the senpai-kōhai relationship is addressed in question 7 (普段あなたは先輩にどうやって話しかけますか。ど の程度の距離感で接しますか。For you personally, when you determine someone is your senpai, how do you talk to them? How polite are you?). The majority of respondents answered that they talk to their senpai using keigo and often that the first thing they do upon seeing senpai is greet them. This signals that people are recognizing the senpai-kōhai relationship through behavior and language use. Since the majority of respondents stated they talk to their senpai using keigo, I argue that, at least in the school setting, listeners can identify senpai and kōhai just by hearing speech patterns and watching behavioral interaction. If someone is using honorific language to someone else (and the other person is speaking casually), it can be concluded that the individual using keigo is the kōhai, whereas the one speaking casually is the senpai. While this is not a fool-proof way to identify who is who, the tone, specific language use, and level of reserve and restraint all aid in identifying the senpai and kōhai. Tying into language use are behavioral patterns. If one person seems to either linguistically and/or physically restrain themselves, it may indicate their position as a kōhai.

Since most people perceive the senpai-kōhai relationship through keigo usage, I 
think it is also important to show exceptions to this convention. Questions 8 (Are there senpai you can talk to without using keigo? If yes, how did you establish that relationship? Also, even if you don't use keigo to them, do you still feel they are superior to you?) and 9 (Do you have kōhai who don't use keigo to you? If yes, did that kōhai use keigo in the beginning? Also, around when did they stop using keigo?) showcase examples of people who are outside the social norm of using keigo to senpai.

$48.5 \%$ (16/33 people) stated that they have a senpai they do not use keigo to and the number one reason cited was that they (they and their senpai) were childhood friends and spoke casually to each other long before they became conscious of the senpai-kōhai relationship. So while they view the senpai as superior, they still report using casual speech patterns. Over half $(51.5 \% \rightarrow 17 / 33$ people) do not have a senpai they speak casually to. Additionally, 11 out of 33 respondents (33\%) stated they have kōhai who do not use keigo to them. The most common reason offered is that they became close with their kohai and either told the kōhai it was okay not to use keigo or the kōhai just eventually stopped using keigo. Not surprisingly, the majority of people $(67 \% \rightarrow 22 / 33$ people $)$ said they do not have kōhai who do not use keigo to them. I expected this answer because once people become conscious of the senpai-kōhai relationship (and consequently start abiding by its social conventions), people tend to adhere to the accepted convention where kōhai use keigo to senpai. 
Finally, since the majority of people do not speak casually to senpai or have kōhai who speak casually to them, I argue that most people adhere to accepted conventions around the senpai-kōhai relationship. This is reflected in the responses to question 10 (あなたは、 後輩があなたに敬語を使う事を期待しますか。Do you expect kōhai to use keigo to you?). $55 \%$ of people (18/33) expect their kōhai to use keigo when addressing them, $33 \%$ $(11 / 33)$ do not expect it, and only $12 \%$ are undecided in some aspect or another.

The fact that the majority of people recognize the senpai-kōhai relationship through keigo usage and expect kōhai to use keigo to them shows that a key behavioral correlate of the senpai-kōhai relationship is keigo usage. Keigo is an important part of the Japanese language, so it is understandable that most people will grow up connecting keigo with showing respect and reverence to those who are older.

\section{$\underline{\text { Limitations }}$}

Limitations of my research include a weakness of the data sample. I only have 33 responses from people mainly based in Tokyo and surrounding areas. Data from elsewhere in Japan would give a better idea of how universal attitudes are. The age range of participants was also limited. Respondents were primarily college students with only a couple of high school students. In order to paint a clear picture of contemporary Japanese attitudes towards the senpai-kōhai relationship, a wider range of participants from middle school to working 
adults is needed. Socioeconomic class was also not considered, but future research might examine whether class is a factor in contemporary attitudes. Needless to say, this project was carried out without funding. Proper funding could help increase the data sample by allowing me to make advertisements to have people take a survey or further be included in research by means of case studies. This could also aid in travel to help widen the data sample by having people of all ages in all prefectures respond. Furthermore, as participants in research are conventionally rewarded with a small token of appreciation (such as a pen or keychain), funding could help provide these gifts.

\section{Conclusion}

The senpai-kōhai relationship plays a role in the individual's educational, professional, and personal life from a very young age. The importance this relationship has within society makes it a relevant topic of study as there are relatively limited studies on the senpai-kōhai relationship's importance to Japanese society, or attitudes about the relationship. It is easy to understand why there are not many studies regarding attitudes about the senpaikōhai relationship, as attitudes are hard to access. The senpai-kōhai relationship is inextricably tied to ideology and the government, schools, and workplaces put emphases on people abiding by social conventions. Thus, individual thoughts and attitudes are hard to access.

While there are many limitations to my research, including flaws in the survey 
Contemporary Attitudes Towards the Senpai-Kōhai Relationship Michiko Yoshinaga 24

instrument, I hope my research will shed light on how young Japanese people view the relationship, as well as spark further interest in pursuing this topic with sound research methodology. I also hope that my research will provide insight into our understanding of the senpai-kōhai relationship. 
Contemporary Attitudes Towards the Senpai-Kōhai Relationship Michiko Yoshinaga 25

\section{References}

Bohn, M. T., \& Matsumoto, Y. (2008). Young women in the Meiji period as linguistic trendsetters. Gender and Language, 2(1), 51-86.

Creighton, M. (1998). Weaving the future from the heart of tradition: Learning in leisure activities. In J. Singleton (Ed.), Learning in likely places: Varieties of apprenticeship in Japan (190-210). New York, NY: Cambridge University Press.

Hamada, T. (1995). Inventing Cultural others in Organizations: A Case of Anthropological Reflexivity in a Multinational Firm. The Journal of Applied Behavioral Science, 31(2), $162-185$.

Heine, S. J., Takata, T., Lehman, D. R. (2000). Beyond self-presentation: Evidence for selfcriticism among Japanese. Personality and Social Psychology Bulletin, 26(1), 71-78.

Ide, S. (1982). Japanese sociolinguistics: Politeness and women's language. Lingua, 57, 357 385.

Itakura, H. (2009). Attitudes towards the use of masculine and feminine Japanese among foreign professionals: What can learners learn from professionals? Language, Culture and Curriculum, 22(1), 29-41.

Kondo, D. K. (2009). Crafting selves: Power, gender, and discourses of identity in a Japanese workplace. Chicago, IL: University of Chicago Press.

Lebra, T. S. (1976). Japanese Patterns of Behavior. Honolulu, HI: University of Hawaii 
Contemporary Attitudes Towards the Senpai-Kōhai Relationship Michiko Yoshinaga 26

Press.

Miller, A. L. (2013). For Basketball Court and Company Cubicle: New Expectations for University Athletes and Corporate Employees in Japan. Japanese Studies, 33(1), $63-$ 81.

Reizei, A. (2012). Uekara mesen no jidai [The era of arrogant attitude]. Koudansha.

Rohlen, T. P. (1979). For Harmony and Strength: Japanese White-collar Organization in Anthropological Perspective. Oakland, CA: University of California Press.

Sano, K. (2014). The study of the senpai-kouhai culture in junior high schools in Japan. Sociological Insight, 6(1), 59-68.

Smith, R. J. (1987). Gender inequality in contemporary Japan. Journal of Japanese Studies, $13(1), 1-25$.

Takeishi, S. (2010). Gakkou bunka no keishou to saisouzou [The succession and recreation of school culture]. Aoki Shoten.

Tanaka, L. (2009). Communicative stances in Japanese interviews: Gender differences in formal interactions. Language \& Communication, 29(4), 366-382. 


\section{Appendix A: Questionnaire Data}

\section{* $\mathbf{Q}=$ Question, $\mathbf{R}=$ Response}

Q1：先輩後輩関係についてどう思いますか ? What do you think of the senpai-kohai relationship?

R1：ちょつとかたくるしい、めんどくさい時もある。

R2：日本はかなり強いと思う。悪い面もあるが、良い面もたくさんある。

R3：先輩や後輩を持つことで、自分が学べることが多いと思います。どのように接すれば先輩や後輩から 慕ってもらえるのか知っておくことは、年功序列が主な日本の社会で生きていく上では特に必要なことだと思 います。また、憧れや理想像として先輩がいるのは目標になって良いことだと思いますし、自分が何かを教 えてあげられたり自分についてきてくれたりする後輩も、人間として自分を高める上で大切な存在だと思いま す。

R4：さまざまな人間関係の中で、総合的に見ると親子関係(家族関係)が一番重要な関係だと思いますが、 社会においては先輩後輩関係が最も重要な関係だと思います。

R5：場所や状況で変わると思いますが、敬語などある程度の礼儀は必要だと思います。

R6：時に面倒な部分はあるが、人間関係には必要なものだと思う。

R7: 楽しい。後輩というだけで可愛く感じるし、先輩というだけで頼もしく感じる。

R8: 重要だと思う。

R9: たいていの場合あってもよいと思います。

R10：大事だと思います。社会でうまくやっていくために、必要なもの

R11：あるのが当たり前で、礼儀として先輩には敬語を使ったりするべき。

R12：生きた年数で立場に上下関係が生まれるということは、人によっては理不尽に思うかもしれないが、 能力により全てが判断されるよりは、全ての人間に対してある意味平等な価値基準であるといえる

R13：物事を引き継いでいくためにも必要な関係性。

R14：横の繋がりだけじゃなくて、先輩後輩の縦の繋がりはとても大事なものだと思います。

R15：日本ならではの関係団体によって厳しさが異なる

R16: 上下の慗がりがあるのはいいと思う。社会人の上司部下の関係の練習にもなる。

R17: あってもいいと思う。

R18：環境によって厳しくする先輩もいたり、優しくする先輩もいたりと接し方が違う関係。

R19：積極的に仲良くなりたい。

R20：人間関係において大事なものであるが、その程度は人それぞれだと思う。私は後輩に対しては厳しく ないのでなにも思わない、

R21：大事なことだと思う。

R22：礼儀ある上下関係は伝統のひとつでもあるけれど、あまり囚われすぎると非常に面倒くさく息苦しいも のだと思います。

R23：良い文化だと思う。 
Contemporary Attitudes Towards the Senpai-Kōhai Relationship Michiko Yoshinaga 28

R24: 大事

R25：どこにでも存在する関係てかんじ。学校でもバイトでも。

R26：先輩を尊敬するのはいいことだと思うが、日本の上下関係は厳しすぎると思う。

R27：あまりこだわりはない。おそらく自分にとって無縁であったからだと思う。

R28：必要なものだと思います。

R29: 大切なもの。

R30：典型的な日本の伝統だと思う

$\mathrm{R} 31$ ：自分より目上の人に対して尊敬の意を込めて接することは、特に日本社会においては重要であると思 います。アメリカにはない日本独特の文化であると思います。また、個人的な意見ですが、先輩後輩関係の 中で重要なのは、敬語を使うかどうかではなく、相手を尊敬している気持ちが充分に表せているかどうかであ ると考えます。

R32：大切だとは思うが、厳しすぎる上下関係はよくないと思う。

R33：年齢や会社、学校に入った年が少し上だというだけで立場がかなり変わるのは少し理不尽な気がしま す。

\section{Q2：日本において、先輩後輩関係は必要だと思いますか。また、それは何故ですか。In terms of} Japan, do you think the senpai-kōhai relationship is necessary? If so, why?

R1：そんなに必要ない気がする。

R2：必要だと思う。仕事上などで必要だと思うから。

R3：はっきりと必要だと言うことはできませんが、その方が社会が整理される気がします。歳だけでランクや レベリングされる日本は個人的には好きではありませんが、その方が組織などを管理しやすいのではないか と思います。

R4：必要だと思います。日本は特に先輩後輩関係を重視する文化が古くから根付いていると思うからです。 また、そのように古くからあるということは、日本人の中に無意識的に先輩後輩関係を重視するという意識が 根付いていて、それに基づいて社会は構成されているので、必要だと思う、というよりむしろ不可欠なもの、な くてはならないものであると思います。

R5：必要だと思います。礼儀は日本の文化としても大切だと思うし、年上の人を敬う気持ちは持つべきだと 思います。

R6: 年上の人を敬う気持ちを表現するために、先輩後輩関係は必要だと思う。

R7：絶対に必要というわけではないが、あった方がいいと思う。部活などにおいて後輩は先輩に教わったり 世話をしてもらったりするから、尊敬の念が必要なため。

R8：必要だと思う。人間関係を円滑にするため。

R9：必要。新しく入った人よりも多くのことを知っていて、先輩から学ぶということができるから。

R10：必要だと思います 先輩のいいところをみつけて自分もそうなりたいと思いそのいいところをまた次の 後輩に受け継いで社会はなりたってるとおもいます

R11：もちろん必要である。社会的に見ても先輩後輩関係は存在し、もし敬語など使えない人がいたら礼儀 がなっていないと思われるから。 
R12: 長く生きた人は、その中身に関わらず、確実に歳若いものよりも多くの経験を持っているからこそ、敬 われるべきであるという儒教的概念は日本人の価値観にすでに刷り込まれており、また言語学的にも密接な 関係が生まれている。これは日本人のアイデンティティーの一角を成しているとも考えられるので、必要なも のと言えるだろう。

R13：必要だと思う。日本は縦社会であるから。

R14：組織を成り立たせるうえで必要だとおもいます。でも必要以上に先輩風をふかしたりするのは嫌いで す。

R15：必要だと思う。日本社会で働くためには必要な上下関係の訓練になるから。

R16: 上の人を立てるという礼儀は大事だから必要だと思う。

R17：必要。ある程度の礼儀は必要だから。

R18：必要だと考えます。年功序列の世の中だから。

R19: 必要だと思う。先輩から教われることもたくさんあるし、礼儀も身につく。何よりも仲良くなれると楽しい R20：必要なものだと大多数の人が考える以上、社会においては必要だと思う。

R21：必要 今までの日本の文化を形作ってきたものだから。

R22：必要ではあると思います。現代は個性的であることが重視されマナーの悪い若者や自己のアイデンテ イティーを強く主張し周りと迎合しないことをクールだと思っている若者が増えていると感じるので、ある程度 の上下関係は人間関係を円滑に保つために必要だと思います。

R23：必要である。年上の人は人生経験があり、自分よりも大人であるはずなので、敬うのは当然であるか ら。

R24：必要 でも能力のない先輩を建前る必要はないと思う。

R25：必要?かな一?わからない。笑 でも、上下関係はっきりするしいいとは思う。

R26: 不要。年齢に関係なく対等に接する方が、仲良くなると思うから。

R27：必ずしも必要ではないがいままであったのだから、なくすことはできないと思う。目上の人への尊敬を 重んじる日本にとって先輩後輩関係は欠かせないと思う。

R28：必要だと思います。社会に出たら上下関係が厳しいので早め知っておくために良いと思います R29：必要。多くの人はサークルにはいったり、バイトをしたりする。そこで必ず上下関係がうまれるから。

R30：必要だと思う。先輩だからしっかりしなきゃという思いが生まれるから

$\mathrm{R} 31$ ：場合によっては必要であると思います。先輩後輩関係は各々の役割を明確にするのに便利であると 思います。例えば、「先輩は後輩の面倒を見る」や「後輩は先輩を見習う」など。

R32：必要。たくさん経験を積んできた先輩から学ぶことは多く、敬意を表すことは大事だと思うから。 R33：先輩後輩関係があることのメリットがいまいち思い浮かばない一方でいじめや、意見がなかなか言え ないなどのデメリットが多く浮かぶので必要だとは思えません。

\section{Q3: あなたの世代は先輩後輩関係についてどう考えていると思いますか。What do you think people of your generation think about the senpai-kōhai relationship?}

R1：ちゃんとしなきゃとは思っているのでは。

R2：他の世代と同じだと思う。しかし、昔の世代よりは緩く考えていると思う。 
Contemporary Attitudes Towards the Senpai-Kōhai Relationship Michiko Yoshinaga 30

R3：少し堅苦しく、窮屈で息が詰まるものだと考えている人が多いと思います。

R4：わたしたちのような 10 20 代は先輩後輩関係をあまり重要だと思っていない、とテレビなどでよく言わ れています。私がそれを実感したことはありませんが、もっと上の世代の方々から見たわたしたちの世代はそ のように見えるのかもしれません。

R5：大切だと考えてると思います。

R6：あまり先輩後輩を意識していない人が増えていると思う。例えば、先輩に敬語を使わないで話す人とか いると思う。

R7：面倒くさいと考えている。

R8：あまり重要に思ってないと思う。

R9：面倒臭いと思っている人もいると思います。

R10：必要不可欠な物だと考えられてる

R11：人によって差はあるが、先輩に敬語を使うことは礼儀であり常識である。

R12：年長者への絶対的敬意や、年長者からの理不尽な要求を順従に受け入れることへの拒絶感は高まり つつあるが、その所属する社会·環境においてより多くの経験を持つ者に対する敬意はまだ残っている気が する。

R13：当たり前なもの。

R14：上の代の人たちより重視はしてないとおもいます。

R15：疑問を抱くことなく受け入れていると思う。

R16：とくになにも。なくなるとは思ってないと思う。

R17: そんなに重く考えていない

R18：当たり前のように、先輩には敬語を使い、後輩には指導する立場の上下関係が成り立っていると思 j。

R19：あって当然のもの

R20：フランクになってると思う。

R21：めんどくさいと思う人もいると思う。

R22: 中学時代などは上下関係が非常に厳しい印象だったが年を追うに連れてみんな考え方が大人になっ ていると思うので、理不尽な上下関係ではなく自分自身の経緯として自然に年上を敬うことが出来るようにな つたと感じます。

R23：少し面倒だが、当たり前だと思っている。

R24：大切に思ってると思う

R25：あたりまえの存在だから、そんな深く考えてなさそう。

R26：面倒くさいと感じていると思う。

R27: 根本はポジティブなイメージを持っていると思う。

R28：面倒臭いと思ってると思います

R29：大切なもの。誰にでもあるもの。

R30：人によると思う

R31：頼もしい関係であると感じることもありますし、場合によっては窮屈な関係であると感じることもある、と 考えていると思います。 
R32：先輩後輩関係が大切なことだとは分かっているが、もっと上の年齢の人たちに比べるとそんなに厳しく ないと思う。

R33：後輩にとっても先輩にとっても必ずしも気分のいいものではないけれど、そういう風になっているから 仕方がないと考えている人が多いと思います

\section{Q4: 具体的にいつ頃先輩後輩関係を意識するようになりましたか。About when did you become conscious of the senpai-kōhai relationship?}

R1：中学、部活など始まってから。

$\mathrm{R} 2$ : 中学校に入ってすぐ

R3：私は高校まで海外で過ごしたので、先輩後輩の概念は大学生に入ってから意識するようになりました。 R4: 中学校に入学して、部活に入って先輩ができてからです。小学校でも部活に入っていましたが、そのと きは先輩後輩関係はあまり意識していませんでした。中学校の部活では、先輩と会ったときは立ち止まって お辞儀をして挨拶をする、という決まりがあったので、そのような特別な行動をとるようになったことがきっか けで、意識するようになったのだと思います。

R5: 中学生です。

R6：中学に入学して部活に入ってから。

R7: 中学

R8: 中学校。

R9：中学生になってから。

R10：中学の部活に入ってから

R11：中学の部活動に参加した時。

R12: 先輩·後輩、という呼び方が使われるのは中学以上が基本的だが、そもそも年上に対する礼儀という 意味では小学生の頃から主に言葉遣いの面で気をつけていた。

R13：中学生になって、部活動を始めてから。

R14: 高校生

R15: 中学校入学、部活に入ってから。

R16: 中学校で部活に入った時

R17：中学生の時

R18：中学1年生のときに部活を始めて意識しました。

R19: 中学生から

R20: 中学校

R21：高校から

R22：中学時代部活に入った時

R23：中学生になり部活に所属してから

R24: 中学校の部活

R25: 小学校の高学年ぐらいから。

R26: 中学生。 
Contemporary Attitudes Towards the Senpai-Kōhai Relationship Michiko Yoshinaga 32

R27：中学生のときでの部活。

R28: 中学に入ってから

R29：日本人はたぶんこの概念を意識したことはないと思う。日本に住んでいると当たり前になっている。お そらく時期は中学生の頃。部活がはじまったころ。

R30：中学校のとき

R31：中学生の頃です。

R32：中学生になり部活動に入ってから。

R33：中学でソフトテニス部に入ったときです。

Q5: あなたは、敬語が人と人の間に距離や壁を作ると思いますか ? また、それは何故ですか。Do you think keigo (honorific language) creates barriers between people? If so, why?

R1：少しつくる。気をつかったりしてフランクにできないから。

R2：作るとは思う。しかしながら、それが必要な場面もある。

R3：作ると思いますが、マナーとしての程よい距離や壁だと思います。やや堅い表現で、くだけた言葉は使 わない、正確な日本語だからです。

R4：あまり思いません。敬語と一ロに言っても、丁寧さには程度があるので、それが人と人との間の距離感 を生むとは言い切れないと思うからです。わたしは先輩には敬語を必ず使うようにしていますが、同じ言葉遣 いでも仲の良い先輩もいれば距離感を感じる先輩もいます、だからわたしは敬語が距離感を生むとはあまり 思いません。

R5：あまり思いません。敬語の使い方によると思います。

R6：普通にタメロで話すよりも敬語の方が改まった表現になるから、距離を感じると思う。

R7：作らない。敬語でもそうでなくてもその人を一人の人間として愛する気持ちは変わらないから。

R8: 思わない。礼儀として必要。

R9：つくる。友達や家族には使わないから。

R10：作ると思います。人を敬う時に使う言葉だからです

R11：作ると思う。敬語は先輩、目上の人に使うというものであると同時に、初対面のひとにも使うことこと が多いのである程度距離がある人に使うという認識があるから。

R12：確かにその可能性は十分に考えられるが、親しき中にも礼儀ありという言葉もある通り、距離や壁は 必ずしも人間関係を構成する上で悪い者ではないと思う。その上で距離や壁ができる理由を述べるのであ れば、それはそもそも日本語において敬語は「距離がある者に対して使う言葉」として作られたから、としか言 えないだろう。あえて立場の違いや上下関係をはっきりさせるために敬語が使われるのであるから、距離や 壁ができるのは当然の結果である。

R13：作らないと思う。敬語であっても親しみを込めることはできると思うから。

R14: ないとおもいます！

R15：壁は作らない。敬語をつかいながらも先輩、後輩とも自由にコミュニケーションが取れると思うから。 いわゆる「タメロ」とは表現方法が違うだけ。

R16：同期の人同士で敬語だと壁を感じる。 
Contemporary Attitudes Towards the Senpai-Kōhai Relationship Michiko Yoshinaga 33

R17：はい。敬語は尊敬するという意味で壁を作るためにあるから

R18：思いません。礼儀のひとつとして、時と場所のけじめをつけるために使っていると思うから。

R19：作らないと思う。話してる表情や内容の方が大切だと思うから

R20：最初はよそよそしいかもしれないけど、仲良くなる過程で邪魔になるものではない。

R21：作らないと思う。

R22：人と場合によるけれど、本音を言いにくいという点では壁をつくる場合もあると思う。

R23：作らないと思う。年上なのに敬語を使わないと逆にギクシャクして気まずい雾囲気になると思うため。

R24：思わない。でも同い年に使うのは距離を感じる。親しくない人には敬語を使う傾向があるから。

R25：あると思う。初対面ならまだいいけど、何回目かで、同い年の人に敬語を使われたりすると、距離感を 感じる時があるから。

R26：思う。敬語を話す時には友達のような感覚で話すことは難しいから。

R27：作ると思う。そこには尊敬の思いが強調されるから。

R28：作らないと思います。気持ちがあれば、距離は縮まると思います。

R29：思わない。ただ尊敬から遠慮がうまれてしまうと、そこに距離ができてしまうのではないか。また憧れ が強すぎる場合も。

R30：思う、相手を敬った言葉だから

R31：きちんとした敬語は時々、距離をつくってしまうと思います。なぜなら、フォーマルな、プライベートでは ない印象を受けてしまうからです。

R32：作ると思う。しかし、その人との関係の深さによって違うと思う。お互いのことをある程度知ってきたら、 敬語を使っていたとしてもそんなに壁を感じないと思う。

R33：敬語を使う相手には極力失礼なことを言わないように意識してしまうので、敬語を使わない相手と比 べると本音が言えなくなるので個人差はあれど距離は生まれると思います

\section{Q6: あなたはどのようにして初対面の人が自分より目上か目下かを判断しますか。How do you determine who is senpai and who is kōhai?}

\section{R1: N/A}

$\mathrm{R} 2$ ：話し方など

R3：まず敬語で話して、歳を聞いて判断します。経験値が関わってくる場合は、その人がその仕事や活動 に携わってきた期間で判断します。

R4：初対面の人にはなるべく敬語で話しかけると思います(それと同じように初対面の人から敬語で話しか けられることが多いです)なので、その段階ではなかなか目上か目下かを判断できませんが、一番単純な判 断基準は学校における「学年」や、会社における「役職」など、そのコミュニティにおいて「年齢」の代わりとして 用いられている単位ではないかと思います。したがって、生年月日から導き出される年齢だけが判断基準で はないと思います。

$\mathrm{R} 5$ ：年齢、学年などを聞きます。

R6：初めて会ったときの見た目や話し方などの印象。

R7：判断しない 
Contemporary Attitudes Towards the Senpai-Kōhai Relationship Michiko Yoshinaga 34

$\mathrm{R} 8$ ：年齢を見る。

R9：外見、態度、

$\mathrm{R} 10$ ：年齢です

R11：見た目、雰囲気

R12：目上、目下という言葉の解釈がしゔらい。敬語を使うべきかどうかの判断ということであれば、最初は 全員に丁寧語を使い、心理的距離が近まり、かつ歳が同じであれば、敬語をなくすし、そうでなければ敬語を 使い続ける。

人を見下すか、敬うかという意味で聞いているのであれば、その人の持つ能力を総合的に判断し、それに対 応する関わり方をする。

$\mathrm{R} 13$ ：年齢や学年。

R14：学年や、所属をききます。

R15：話してみて、雰囲気などから。わからないときは学年などを聞く。

R16: 年齢

R17：話し方、外見

R18：初めての人には必ず敬語を使用して、情報を聞き出して判断する。

R19：外見、年齢などから

R20：見かけ

$\mathrm{R} 21 ：$ 身なりや顔からして年上かどうか

$\mathrm{R} 22$ : 学年を聞く

R23: N/A

R24：判断しない。みんな目上だと思って接する。

R25：見た目。か、何年生ですか?とか聞いてしまう。

R26: 学年を聞く。

R27：話してみて、学年をきく。

R28：初対面の人は基本的に目上であるという考えの元でお話しします

R29：見た目。

$\mathrm{R} 30 ：$ 年齢と周りの人との関係性

R31：落ち着きや言葉遣い、自分に対する接し方によって判断します。

$\mathrm{R} 32 ：$ 直接年齢をきく、もしくは周りの人にきく。

R33：学年や年齢を聞くまで分からないです

Q7：普段あなたは先輩にどうやって話しかけますか。どの程度の距離感で接しますか。For you personally, when you determine someone is your senpai, how do you talk to them? How polite are you?

R1：敬語で話す。仲がよくなると冗談などを言ってしまったりもする。

$\mathrm{R} 2$ : 敬語で。失礼にならない程度に、気軽に接している。

R3：敬語で挨拶をしてから話しかけます。先輩の邪魔にならないよう、相手の都合を気遣って接します。 
R4：基本的には敬語で話しかけます。どんなに仲が良い先輩でも敬語を使うように心がけています。でも距 離感があるようにはしないように、笑顔で話しかけるようにしています(笑)

R5: お疲れ様ですと声をかけてからあまり近づき過ぎずに話します。

R6：敬語を使って、近づきすぎず離れすぎない距離感を保って話す。

R7：敬語だがとてもフレンドリーに。たまにタメロが混ざることもある。

R8: 敬語で。

R9：敬語を使うけれどあまり同い年と距離感は変わりません。ただ、同い年よりは気を使います。

R10：敬語で下から話しかけます

R11：仲のいい先輩であればがちがちの敬語ではない軽く使う。かなり年が上の先輩や親しくない先輩に はしつかりと使う。

R12: 先輩でも親交も深ければ丁寧語レベルで対応し、時にはスラングなども混ざりうる。一方、そこまで交 流がなかったり、とても歳が離れていれば、尊敬語謙譲語を使った話し方をするようにしている。

R13：挨拶をする。冗談を言えるような距離感。

R14：あまり先輩ということは意識しません。

R15：敬語をつかって話す。距離は近すぎず、かつ不自然にならない程度の距離を保つ。

R16：挨拶、お礼は丁寧にする。普通に話す時はフランクに。

R17：最初は敬語で話す。お互いのことが分かってきたらフランクな話題も話す

R18：敬語で話しかけます。距離感は友達と同じです。

R19: どれくらい仲が良いかによって、冗談を言ったりもするし、緊張したりもする

R20：敬語

R21：ともだちと変わらない

R22：敬語はきちんと使いつつ、普通に話したいことは話していると思います。

R23：あくまで先輩であり、友達よりは少し堅い。

R24: 敬語。ある程度の距離をとって

R25：敬語が多いけど、親しい先輩とかだとタメ語になるときもある。

R26: 最初は控えめに接する。慣れたら親しく。

$\mathrm{R} 27$ ：敬語とフランクな話し方をおりまぜて話す。

R28：ある程度の敬語を使って話してます。距離は近いです。でも、距離を縮めるまでに 1 年かかりました

R29：敬語。ただ仲良くなった場合、時々ためぐちになる。

$\mathrm{R} 30$ : 友達以上教授未満

R31：あまり距離感を感じられない程度の柔らかい敬語を使って接します。

R32：敬語に気をつけながら話す。近すぎず遠すぎない丁度いい距離感。

R33：あまり自分からは話しかけられないです。同い年の友達と比べるとかなり距離があります。

Q8: あなたには、敬語を使わずに話せる先輩はいますか。はいと答えた場合、どのようにしてその関係は 成立しましたか。また、あなたは敬語を使わなくてもその先輩を目上だと捉えますか。Are there senpai you can talk to without using keigo? If yes, how did you establish that relationship?

Also, even if you don't use keigo to them, do you still feel they are superior to you? 
Contemporary Attitudes Towards the Senpai-Kōhai Relationship Michiko Yoshinaga 36

$\mathrm{R} 1 ：$ 日本人ではいない。極力敬語を使う。

R2: いいえ。

R3: はい。OOに住んでいたときは、高校に先輩後輩の概念が存在しなかったので、年上の日本人にも敬 語を使わずに話していました。敬語を使わなくても目上だと捉えています。

R4: いません。敬語を使わなくていいよ、と言ってくれた先輩もいましたが、自分的にそれは申し訳ないの

で、敬語を使うようにしています。(とても仲が良いと時々ぽろつとタメロが出てしまうこともありますが)

R5: いいえ。とらえます。

R6: いない。

R7: いいえ。

R8: いない。敬語で話す事で目上だと捉える。

R9: はい。小さい頃から知っている。年齢を気にしない団体の中にいて、敬語じゃなくてよいと言われてい るから。

R10: いません

R11: はい。恋人になったため。

R12: 先輩から友達という存在に変化した際は、敬語をなくすこともある。敬語を使わない場合、本来友人に 対して使うような気遣いはするが、必要以上に配慮することはしない。

R13: いいえ。

R14: はい。学部の先輩であまり目上とは意識してないです。

R15: いいえ。

R16: いない

$\mathrm{R} 17$ : 基本的にいない

R18：小学生の時から仲がいい人には敬語にするタイミングがつかめず使わないでいる。目上だと捉えて います。

R19：はい。高校の部活で、先輩でも敬語は無しというきまりがあった。でも尊敬する部分はたくさんあるか ら先輩に変わりはない

R20: いいえ

R21: いない

R22: いる。同じ留学先に留学したひとつ上の人とは同じ立場で学ぶものとして逆に距離が出来ないように タメ語で話してほしいりと言われたから。やはり年上は経験值が違うのでタメ語であっても自然と尊敬してい ます。

R23: いない。

R24: はい。小学生の時から友達だった人。目上だと捉える。

R25: はい。先輩も敬語を使わなくていいよって言ってくれたから。でも、目上の人だとは思ってる。

R26: いいえ。

R27：はい、何回も遊びにいき仲良くなった。敬語がなくても目上の人だと認識している。

R28: いないです

R29：はい。敬語をなくして距離感を縮めただけであって、尊敬の念は常にある 
R30：はい バイト先の高校生の子は私より長く働いているので先輩です、捉える

R31：はい。「敬語を使わなくてよい」と言われて成立しました。初めは違和感を感じましたが、その先輩は能 力的にも性格的にも優れているので、今も目上であるという認識を持っています。

R32: いる。アメリカで知り合った人には年上であったとしても敬語はつかっていない。目上だと捉えてはい るが、敬語を使うときの方が先輩という認識が強い。

R33: いいえ

Q9: あなたに対して敬語を使わない後輩はいますか。はいと答えた場合、その後輩は最初は敬語を使って いましたか。また、その後輩はいつ頃敬語を使わなくなりましたか。Do you have kōhai who don't use keigo to you? If yes, did that kōhai use keigo in the beginning? Also, around when did they stop using keigo?

R1: N/A

R2: いいえ。

R3: はい。これもまたOOに住んでいたときの話なので、最初から敬語は使っていませんでした。

R4: いません。時々タメロを使われることもありますが、それはふざけて、というか面白半分なので、日常会 話が完全にタメロの後輩はいません。

R5: いいえ。

R6: N/A

R7：はい。使っていた。私が、同い年と知って、使わなくていいよと言ってから。

R8: いない。

R9: はい。もともとよく知っていて使っていない。

R10: いません

R11: N/A

R12：使わないというより、海外生活が長い影響で使えない後輩はいる。

R13: いいえ。

R14: いいえ。

R15: いいえ。

R16: いない

R17：はい。仲良くなってから使わなくなった

R18: いません。

R19：はい。高校の部活の後輩。半年ほど経ってから

R20: いない

R21：いない

R22: いない

R23: N/A

R24：小学校の時から友達だった人。最初っから

R25: N/A 
Contemporary Attitudes Towards the Senpai-Kōhai Relationship Michiko Yoshinaga 38

R26: いいえ。

R27：はい、初めは敬語だったが何回も遊びにいき使わなくなった。

R28: いいえ。

R29: いる。使っていた。3ヶ月後

R30：はい はい 慣れてきた頃

R31：はい。最初は敬語を使っていましたが、使わなくて良いことを伝えると、その瞬間から使わなくなりま した。またアメリカにきてから使わなくなりました。

R32: いない。

R33: いいえ

Q10：あなたは、後輩があなたに敬語を使う事を期待しますか。Do you expect kōhai to use keigo to you?

R1：どちらでもよい。あまりかたくるしすぎるのも、。

$\mathrm{R} 2$ : 少しは。

R3: はい。

$\mathrm{R} 4$ ：はい、期待します。

R5：そこまで期待しません。

R6：敬語を使うものだと思うが、使わなくてもあまり気にしない。

R7: どちらでもいい。

R8：ある程度は期待する。

R9:はい。

R10:はい。

R11：期待する

R12：特に期待はしないが、常識的なこととして、できて当然だと考えている。

R13:はい。

R14: いいえ。

R15：期待する。

R16:はい

R17: いいえ

R18：少し期待します。

R19：部活やサークルであれば。ただ、友達として知り合ったならむしろ敬語は使ってほしくない

R20: いいえ

R21：期待する。

R22：ある程度は使って欲しいが、強いることはしたくないと思う。敬語を使うことで息苦しいと感じて欲しくな い。

R23:はい。

R24: はい。 
R25：何か頼まれたりするときには、期待するかも。でも、普段の生活の中でたわいもない会話であったら、 普通の口調でいいかも。

R26: いいえ。

R27: いいえ。

R28: いいえ。

R29: する

R30: いいえ。

R31: いいえ。

R32: はい。

R33: いいえ。

Q11：あなたは、先輩と後輩は友達になれると思いますか、それとも完全に違う階級に属していると考えま すか。あなた自身は、あなたの先輩と友達になれますか。Do you think senpai and köhai can become friends? Or do you think they exist on completely separate levels? For you personally, can you become friends with your senpai?

$\mathrm{R} 1:$ なれる。多少のに距離感は出るが仲良くはなれる！

R2：思います。なれると思うし、なっています。

R3：はい。気が合えば友達になれると思います。先輩後輩は階級ではないと考えます。

R4：違う階級ではないと思います。敬語を絶対に使う、と言いましたが、その先輩(または後輩と)友達になっ たからといって、敬語を使うのはやめないと思います。一方で、私のように考えている人は少ないのではない かと思います。

R5：友達になれると思うし、わたしもなれます。

R6：友達と同じくらい仲良くなることもあると思うが、自分にはそういう先輩はいないと思う。

R7: はい。

R8: はい。

R9：なれると思います。

R10：なれるとおもいます。このあいだ先輩に遊ぼうと誘われたからです

R11：敬語は使うが、友達のようにはなれると思う

R12：先輩が恋人という存在になりうる以上、友達になることも可能であると考える。恋人も友達も、両者が 対等でなければ成立しない関係である。

R13：友達にもなれると思う。

R14:はい。

R15：友達になることは可能だと思う。ある程度敬意をはらいながら友達付き合いすれば良い。

R16: なれる

R17：思う。敬語を使っていても友達にはなれるから

R18：友達になれると考えています。わたし自身も、私生活でよく先輩と遊びます。

R19：先輩とはそのままだと思う。でも、友達のように仲良くなりたい 
Contemporary Attitudes Towards the Senpai-Kōhai Relationship Michiko Yoshinaga 40

R20：友達にはなれても、先輩後輩という関係は変わらないと思う。

R21：友達ではないと思う。

R22：なりたいとは思うが相手の反応次第だもと思う。

R23：友達になれると思う。敬語を使っていても心を許しあえば本音も話すことができると思うから。

R24：難しい。小さい頃は仲良くできたが今はきつくなってきた。

R25：友達になれると思う。完全に違う階級だとは思わない。先輩とでも友達になれる。気持ち次第かな

$-?$

R26: なれる。

R27：はい、友達になれている。

R28：友達になれると思います

R29: 思j

R30：なれると思う はい

R31：なれると思います。

R32：友達になれると思う。

R33：なれるとおもいます

Q12:（問 11 で「はいと答えた場合)あなたは単なる「先輩」と「友達である先輩」をどのようにして判断し分 けますか。For those that answered 'yes' to question 11, how do you differentiate "senpai" versus "senpai who is also friend"?

R1：一緒に遊びに行ったりフランクな話ができるかどうか。

$\mathrm{R} 2$ : 親しみやすさ、仲の良さ

R3:「先輩」は組織内で先輩と定義される人で、「友達である先輩」は個人的に約束を取り付け組織外で会う 人、と考えています。

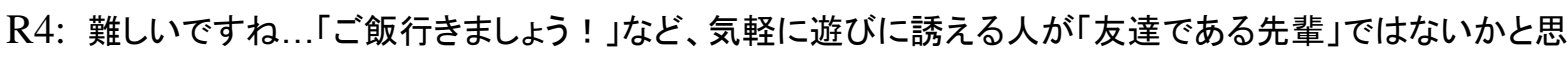
います。

R5：仲の良さです。

R6: 仲の良さ。

R7：仲の良さ。先輩の中でも同期と同じくらい仲がいい人が多いため。

R8: 人間性。

R9：気を使わずに話ができるか。何もないときにどうでもいい話をできるか。

R10：遊んだことがあるかないか

R11：冗談やふざけたことが出来るかどうか 。

R12: 先輩から友達になれるかは、先輩が判断することであり、先輩が友達口調の許可を出すことによって 成立するので、後輩が判断することではない。

R13：先輩後輩関係であるコミュニティ以外の場所で、一緒に遊びに行けるかどうか。

R14：気がゆるせるかゆるせないかで判断します。

R15：自分との距離の近さを自分で判断して分ける。ある程度の冗談やタメロが許されるかどうか、など。 
Contemporary Attitudes Towards the Senpai-Kōhai Relationship Michiko Yoshinaga 41

R16：仲がいいか普通か

R17：遊びにいくかどうか

R18：業務連絡以外の話が出来る人は友大。

R19：知り合った状況に応じて

R20：話しやすいかどうか?？

$\mathrm{R} 21$ ：友達と先輩は違うと思う。

R22：どこまで言いたいこと、自分の本音を言えるか。

R23：何気ないことも話せるかどうか。

R24: N/A

R25：すごく親しいか、そうじゃないか。

R26：何でも話せる関係かどうか。

R27：距離感が近いかどうか。

R28：距離がどれくらい近いかによって判別しています

R29：仲の良さ 会う頻度

R30：特にわけない

R31：一緒にいる時間が長いかどうか、何でも話せるかどうか、その先輩が間違っているときに指摘できる かどうか

R32：自分と対等の立場で話してくれ、なんでも相談できる人を「友達である先輩」と判断する。

R33：話が合う、あまり先輩らしくない(いばっていない)人とは仲良くなれますが、あまり話さない先輩や態度 が大きい先輩は単なる先輩止まりだと思います 


\section{Appendix B: Full Questionnaire with Translations}

Personal information 個人情報

1. Date of Birth 生年月日

2. Full name (optional) 氏名

3. Occupation (if college student, where, what major, and what year?)? 職業（大学生な ら学年・学部・大学名)

4. (If you answered yes to 3) Are you doing part-time job?（3 で学生と答えた場合）ア ルバイトしていますか?

5. Have you been abroad? If so, where and for how long? 外国に行ったことはあります か。（「はい」の場合）場所と期間は?

6. Have you studied abroad? If so, where and how long?

7. 留学しましたか。（「はい」の場合）場所と期間は? How did your study abroad impact you in terms of returning to Japan?

8.（7 ではいと答えた場合)留学の経験は、帰国後のあなたの文化観にどのような影響を与 えましたか。

Statistical information

9. What is your opinion of the senpai-kohhai relationship? 先輩後輩関係についてどう思 いますか。

10. Do you think the senpai-kōhai relationship is needed in Japan? Why or why not?日 本において、先輩後輩関係は必要だと思いますか。また、それは何故ですか。

11. Do you think it's possible that there won't be a senpai-kōhai relationship in the future? 将来、日本から先輩後輩関係がなくなる可能性はあると思いますか。また、そ れは何故ですか。

12. What do you think your generation thinks of the senpai-kōhai relationship? あなた の世代は先輩後輩関係についてどう考えていると思いますか。

13. When did the senpai-kōhai relationship start becoming an everyday part of your life (for example, middle school). ? 具体的にいつ頃先輩後輩関係を意識するようになりま したか。

14. What kind of senpai do you have (for example, circle, job, etc.)? あなたにはどんな先 輩がいますか（例えば、サークル、バイト等）。

15. What kind of kōhar? あなたにはじんな後輩がいますか。

16. Do you think that keigo creates a barrier between people? Why or why not? あなた は、敬語が人と人の間に距離や壁を作ると思いますか?また、それは何故ですか。

17. How do you determine who is senpai and who is kōhar? あなたはどのようにして初対 面の人が自分より目上か目下かを判断しますか。 
18. Do you have senpai who are younger than you? あなたには年下の先輩がいますか。

19. Do you have kōhai who are older than you? あなたには年上の後輩がいますか。

20. If you said yes to having a younger senpai or an older kōhai, how did you determine these relationships? How did you determine who was the senpar? （ 2 ・ 3 に対して 「はい」の場合）どうやってその関係は成立しましたか。

21. For you personally, when you determine someone is a senpai, how do you talk to them typically? How polite are you?

22. 普段あなたは先輩にどうやって話しかけますか。どの程度の距離感で接しますか。

23. Do you have senpai that you speak casually to? If so, how did both of you agree to a more casual relationship? Do you still view the senpai as your senior? あなたには、 敬語を使わずに話せる先輩はいますか。はいと答えた場合、どのようにしてその関係は 成立しましたか。また、あなたは敬語を使わなくてもその先輩を目上だと捉えますか。

24. Do you have kōhai that speak casually to you? If so, did they start off using keigo? When did you determine that the kōhai could be on the same level as you? あなたに 対して敬語を使わない後輩はいますか。はいと答えた場合、その後輩は最初は敬語を使 っていましたか。また、その後輩はいつ頃敬語を使わなくなりましたか。

25. As a senpai, do you care if kōhai use keigo to you or not? あなたは、後輩が敬語を使 うかどうかが気になりますか。

26. In regards to your senpai, do you ever have times that you wonder why you must be so polite to someone who is not very much older than you, or doesn 't seem better than you? If so, how do you communicate with this type of senpar? （特に年齢が離れ ている訳でも、自分より何かに秀でている訳でもないのに）何故目上の人に対して敬語 を使わなければならないのかと不思議になった事はありますか。はいと答えた場合、そ のような目上の人とはどのように接しますか。

27. In regards to kōhai, when you determine that they are kōhai, do you immediately start speaking more casually? 相手が自分より目下・後輩だと判断した場合、あなた は寸ぐに友達口調で話し始めますか。

28. Do you expect kōhai to use keigo to you? あなたは、後輩があなたに敬語を使う事を期 待しますか。

29. Do you think that senpai and kōhai can be friends or are they distinct categories that have boundaries? Can you be friends with your senpai? あなたは、先輩と後輩 は友達になれると思いますか、それとも完全に違う階級に属していると考えますか。あ なた自身は、あなたの先輩と友達になれますか。

30. How do you determine who is a friend versus senpai/kōhar?（問 11 で「はい」と 答えた場合）あなたは単なる「先輩」と「友達である先輩」をどのようにして判断し分 けますか。

31. Is the senpai-kōhai relationship in companies different from that of schools? Why or why not? What are some differences and similarities? 会社内での先輩・後輩関係 
Contemporary Attitudes Towards the Senpai-Kōhai Relationship Michiko Yoshinaga 44

は、学校におけるそれと異なりますか。その理由は何ですか。相違点・類似点を挙げて ください。

32. Japanese companies typically follow a traditional structure where the longer you work at the company, the higher your salary. In terms of promotion, do you think it is possible for you to pass a senpai or a kōhai to pass you? If so, how would this impact your relationship? If you "pass" a senpai, would you still use keigo with them? 日本の会社では通常、年功序列制を取りますが、会社における後輩が先輩より も昇進することは起こりうると思いますか。はいと答えた場合、この昇進はその両者の 関係にどのような影響を及ぼすでしょうか。もしあなたが先輩よりも昇進した場合、そ れでも敬語を使い続けますか。

33. For students who are working part-time jobs, how does your level of keigo change when talking to a company senpai rather than a school senpai? アルバイトをしてい る場合、職場で使う敬語と学校で使う敬語の程度に差はありますか。差がある場合、ど のように異なりますか。

Study abroad: if you have never been abroad for longer than 1 month, you can skip this section. If you have not yet gone abroad, please don`t answer this section.（1 か月以上の海外留学／海 外滞在経験のある方のみ)

34. How relevant was the senpai-kōhai relationship when you were abroad? 海外滞在 中、身の回りにどの程度先輩・後輩関係はありましたか。

35. Did you find that you could speak more casually to people who would be considered senpar? 海外滞在中、日本なら先輩にあたる人に対して、あなたはより友達口調で接す る事ができましたか。

36. When interacting with other native Japanese, did you try to speak a language other than Japanese? If so, did you also use Japanese? Did the foreign language have a form of keigo, and if so, did you use it? 現地で他の日本語母語話者と接する際、日本 語以外の言語と使いましたか。はいと答えた場合、あなたは日本語を併用しましたか。 また、あなたが滞在した現地の言語に敬語はありましたか。あった場合、あなたはそれ を使いましたか。 